\title{
Images of Riding, Loading and Treated Donkey as a Burden Beast in Ancient Egypt
}

\author{
Abdallah Mohammed Diab* \\ *Lecturer at Higher Institute of Tourism and Hotels \\ (E.G.O.T.H) Ismailia
}

\begin{abstract}
This paper traces different ways of controlling and treating donkeys whether riding or loading, as an important beast of burden in ancient Egypt. These ways of control include; sticks, tugging tail/leg, and the headlock. Most of these illustrations date back to the Old Kingdom, this may be due to the abundance of agriculture scenes which cover great spaces of the wall of these tombs. Also, the paper deals with the size and the shape of the loads which he carries. It deals also with cases of abusing the animal and the consequences which led sometimes to its death.
\end{abstract}

Keywords: donkey, load, stick, pannier, control, treatment, tugging, headlock.

\section{Introduction}

The main reason to address this subject was the rare data available dedicates to this animal, except the work of Janssen, about donkeys in Deir el Medina (Janssen, 2005). Although this animal has sized a great spaces on the wall of tombs and has considered as a useful economic transportation tool, especially in agriculture and expeditions to the remote deserted areas. This paper is trying to highlight his role as a burden beast, with several ways of control and treatment by the Egyptian.

A species of the wild donkey (Equus africanus) is known to have inhabited northeast Africa, extending from Nubia to at least the southern part of the Nile Valley and also to parts of the Eastern and western desert (Redford, 2001: 4790). The donkey was first domesticated in the Prehistoric or Early Dynastic Period (c.3000-2686 BC) and some of its earliest representations appear on slate palettes from this time (LIoyd, 2010: 384). Bones from the Predynastic site of Ma'adi are referring to domestic donkeys (Bard, and Shubert, 2005: 358). By the late Predynastic period, the donkey is a domesticated and appears in the record in the Early Dynastic period (Capart 1905: Fig.175; Hawass, 2010: 47; Bunson, 2002: 214; Wilkison, 1999: 137; Redford, 2001: 479).

The Egyptian donkey was a fairly large animal. The images show it generally as grey and often with a dark stripe along the length of the back and a short stripe across the shoulders (Bard and Shubert, 1999: 358), and were employed in pharaonic Egypt for long-distance travel (Holihan, 1996: 32), but their limited carrying capability and the need for bringing a supply of water for them imposed limited on the length of such trips (Malek, 1986: 59). Close to the late Old Kingdom or the beginning of First Intermediate Period, there is installation supplying depots at regular distances in order to free their backs for other goods that needed to be transported (Forster, 2007: 3). This distance most probably relates to the donkey's ability to go without water for two or three days, an ability the Egyptians certainly made use of (Forster: 2007: 5). 
The six dynasty Harkhuf in his tomb at Thebes, reported that he returned from one of his missions to Nubia with three hundred donkeys laden with all sorts of trade goods, and in the same period Sabni took one hundred laden donkeys with him when he went south to recover the body of his father (Simpson, 2003: 410; Redford, 2001: 479). Donkey caravans were used on the desert roads for communication with the mines and quarries, as well as foreign expeditions. Local workmen regularly hired donkeys at high prices for local transport work, as seen in Deir El-medina community for example (Lsko, 1994: 47; Muhs, 2016: 130; Wilkinson, 2007: 171), where the going rate for donkey rental seems to have been 3 3/4 sacks of grain a month (Cline and Rubalcaba, 2005: 136: Szpakowska, 2007: 20; see also J. Janssen 2005: 69-47). Scenes from the military campaigns of Ramesses II show the army in camp using donkeys carrying panniers loaded with supplies and equipment (LIoyd, 2010: 384). Generally, Donkeys were the most popular type of pack animals and are often represented being loaded with grain and other farm products in baskets and saddle bags that were specially designed for this purpose (Peck, 2013: 167). The donkey had many uses in the agricultural estate where they were used for threshing corn, transporting sheaves and were generally regarded as beasts of burden (David, 2003: 203: Erman, 1894: 493; Redford, 2001: 479). By the Old Kingdom, donkeys are frequently shown in tomb reliefs as a heavy loaded animal. They are easy to look after, can also survive on little water and poor quality forage, and are long-lived. They are shown carrying corn sheaves, or with net or basket panniers suspended on each side of their backs (LIoyd , 2010: 484; Bard, and Shubert, 2005: 358), every large agricultural estate in ancient Egypt owned many hundreds of these hardworking donkeys (Holihan, 1996: 30). Today the donkey is still used for carrying crops over short distances (Partridge, 1996: 97: LIoyd, 2010: 384; Bard, and Shubert, 2005: 358). Sticks were always in the hands of those were charged to control the animal, or as a way of punishment, waving to urge and making him on a straight path without deviation.

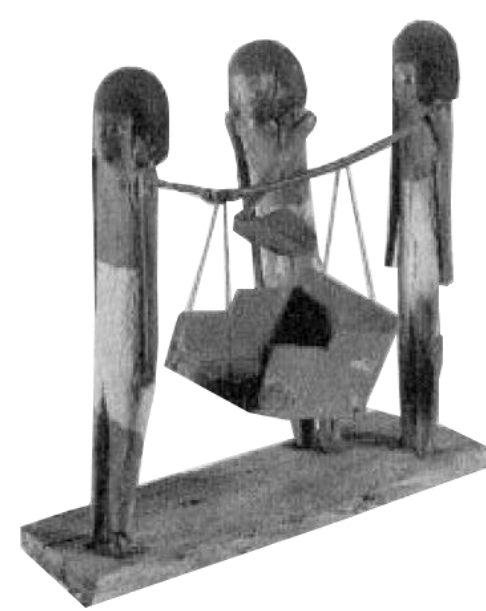

Fig.1 David. 2003: 302

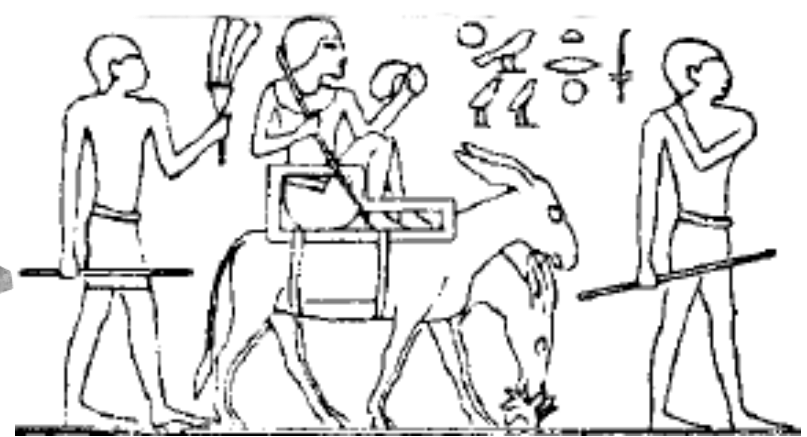

Fig.2 Hassan, 1944: 104 


\section{Ridding donkeys}

The ancient Egyptians do not appear to have liked riding donkeys (LIoyd, 2010: 383). He is not held in very high regard in modern Egypt and this seems to have been the case in ancient Egypt too (Partridge, 1996:78). Ancient Egyptian apparently opted not to ride on the back of the donkey. The reason for this avoidance perhaps it was simply viewed by the Egyptian as undignified to do so (Houlihan, 1996:31). There are only a few images of people riding on donkey back (Peck (2013: 167). Nobles in particular, however, did not like to ride them (David: 2003: 203). Although some Elites traveled in a sedan between a couple of donkeys (Bard, and Shubert, 2005: 358). If the donkey was ridden at all regularly in ancient Egypt, the practice was very likely confined to the lower strata of Egyptian society. Nevertheless, there is a few rare depiction of it using a donkey seat or saddle (Houlihan, 1996:31). One example of a donkey saddle has been displayed in the Berlin Museum, which dedicated to this practice (Fig. 1) (Erman, 1894: 490; David, 2003: 302). Littauer and Crouwel stated that the use of donkey seat by the Egyptian indicate the Egyptian was still in a primitive stage of equitation (Littauer, \& Crouwel, 1979: 96). There is also a saddle made from clothing to protect the back of the animals, one of these saddles clothes found at Red Sea coastal site of Quseir elQadim. It was made from various layers of small fragments of cloth sandwiched between two layers of coarse material (Nicholson, and Shaw, 2000: 292).

A few rare occasions were recorded during the Old Kingdom portraying tomb owners riding on donkey's back (Collins, 2002: 106). Contrary they are seldom attested as riding in the Middle Kingdom (Kopp-junk, 2013: 135). The following examples of contains a chair or a sedan placed over donkey's back beside a stick in the hand of the rider and the two runners accompanying the animal as a means of controlling. Examples of these cases come from the $5^{\text {th }}$ dynasty rock-tomb of Khuwiwer at Giza, showing two donkeys supporting a sedan chair on their backs accompanied by two runners. One walks ahead of the donkey to clear the way while the other follows behind to drive the donkey and fan his master as he sits in the chair (Fig.2) (Hassan, 1944: 232, 256, Fig.104; Lepsius, 1913: PL.43a; David, 2003: 302; Erman, 1894: 409). Another example from the same dynasty in the mastaba of Niankhkhnum and khnumhotep at Saqqara, where the tomb-owner is portrayed riding in a wooden chair that has been strapped on the backs of a pair of donkeys (Fig. 3) (Altenmüller, and Moussa, 1977: 113-115, Fig.42; Houlihan, 1996: 31; Smith, 1949: 301; Donovan, and McCorquodale, 2000; Fig. 9.15; Bárta, 2011: 168), in a way resembling those used to ride Indian elephants (Scanlan, 2000: 89, Fig. 9.15). Save these rare scenes in Egyptian iconography, only foreigners were depicted on the backs of donkeys. Asiatic princes are shown riding donkeys side-saddle on three Egyptian stelae of the $12^{\text {th }}$ dynasty from Serabit al-khadim in Sinai. 
The first scene showing a man seated on a donkey which is being led by one boy and driven by another. The seated figure is, as the inscription above states,

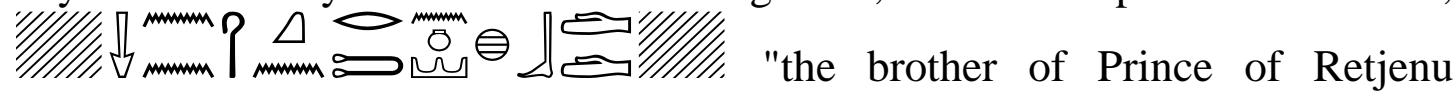
Khebdedem", the man behind carries a large vase in his left hand, the other hand held a stick resting on his shoulder, this man was "His attendant $\Delta$ d4 "Keqbi" (Fig.4) (Gadiner, and Peet, T.E (1955: 114, PL. XXXVII). The other scene showing a man seated on a donkey which is driven by a boy. Over this

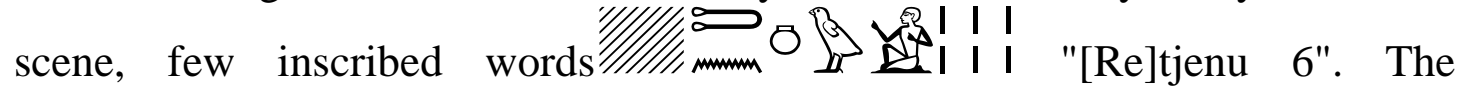
remaining signs give the names of one or more of these three figures. The donkey led by a man and the one behind raising a stick (Fig. 5) (Gardiner, and Peet, T.E (1955:119, PL. XXXIX). The third relief of a man riding on a donkey, the animal is led by a man carrying a spear over his left shoulder and is followed by another man armed also with a spear and a throwing stick. The man on the donkey holds an adze in his left hand, and a short stick in his right maybe for urging the donkey. The man leading the donkey is called 'Shekam', the man behind is called 'Apim', and the bodies of all three are painted yellow, referring to their Asiatic origin (Fig. 6) (Gardiner, and Peet, T.E (1955:206, PL. LXXXV).
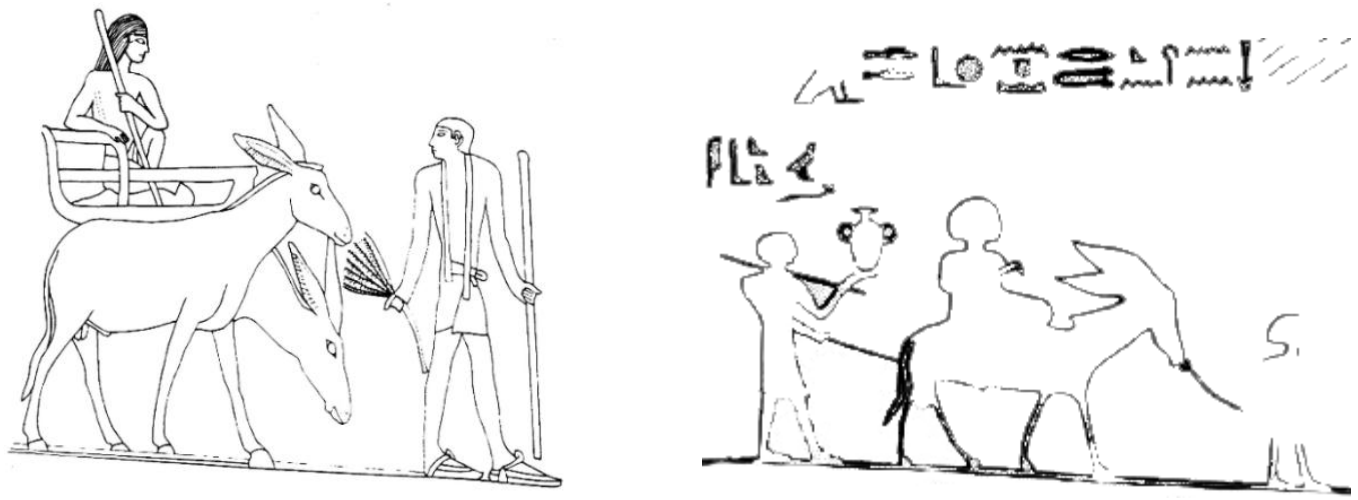

Fig.3 Donovan and McCorquodale, 2000: Fig. 9.15. Fig.4 Gadiner and Peet, 1955:Pl.XXXVII

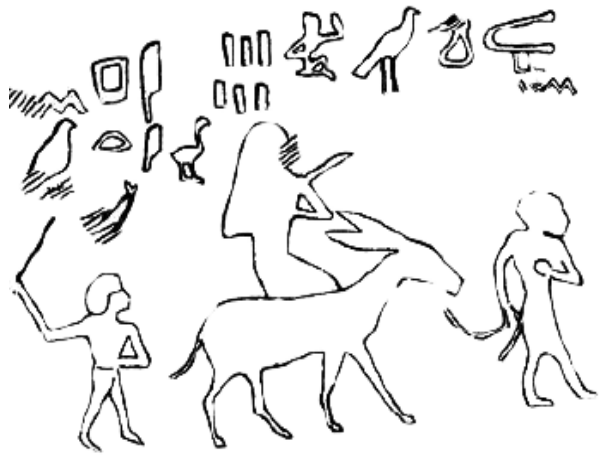

Fig.5 Gardiner and Peet, 1955: Pl. XXXIX

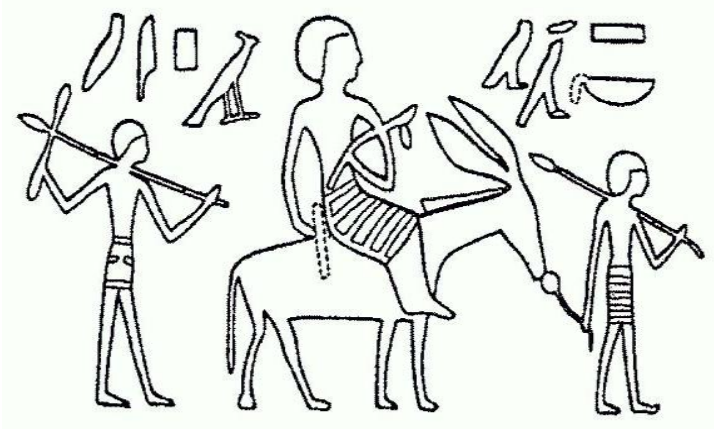

Fig.6 Gadiner and Peet, 1955: Pl.LXXXV 
The $12^{\text {th }}$ dynasty rock-tomb of Khnumhotep III at Beni Hassan had a relief of two children placed in a pannier on the back of a loaded donkey,(Newberry, 1893: PL.XXXI; Woldering. 1963: Fig. 32; Klebs, 1922: Abb. 120-121; Lepsius, 1913: PL.133) This scene was part of a convoy of Asiatic Bedouin came to the nome $16^{\text {th }}$ at Bani Hassan (Fig.7) (McCorquodale, 2000: 6, Fig. 1.9; Bard and Shubert, 1999: 218; Lepsius, 1913: PL.133). Another evidence recorded on a scarab, dated to the $15^{\text {th }}$ dynasty, now in the Ägyptisches Museum, Berlin, also bears an image of an Asiatic prince seated on the back of a donkey (Houlihan, 1996: 31). Although the Egyptians are seldom represented as riding animals even after the introduction of the horse in the second intermediate period, they recognized this as a custom of the people of Asiatic origin (Smith, 1981: 202, Fig. 200).

The best reference to a foreigner riding a donkey comes from the $18^{\text {th }}$ dynasty mortuary temple of Queen Hatshepsut at Dier el-Bahari, where a short caption written above a little saddle donkey on a fragment of wall relief, now in Egyptian Museum. It identifies the donkey as the mount of the Queen of Punt,

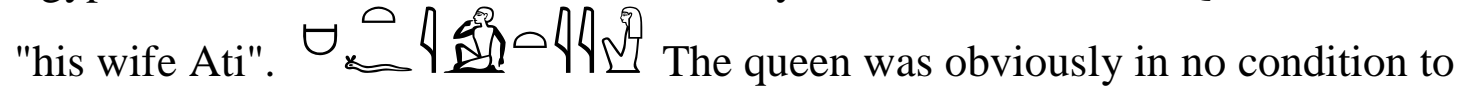
walk, due to her tremendous obesity (Fig. 8) (Naville, 1898: PL. LXIX; Mariette, 1877: PL. 5: Houlihan, 1996: 32; Monderson (2007: 28, Fig. 8; Sethe, 1914: 325-1). Behind her husband a donkey with a saddle, and a text above

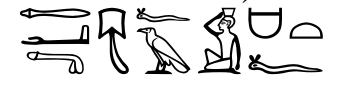
the "donkey which carries his wife." (Erman, 1894: 512). This may be seen by the ancient Egyptians as funny since they themselves apparently did not ride donkeys (Collins (2002: 124; Sethe, 1914: 325-5). Tuthmosis III's historical stela from Gebel Barkal describes how the local rulers were forced rode away on donkeys, after their defeat at the battle of Megiddo in Palestine. Some blocks are now in the Ägyptisches Museum in Berlin, dating from the reign of King Taharqa in the Twenty-fifth dynasty, shows a group of non-Egyptians (probably Kushites) is riding on donkeys that have elaborate saddle-cloths on their backs (Houlihan, 1996: 31-32).

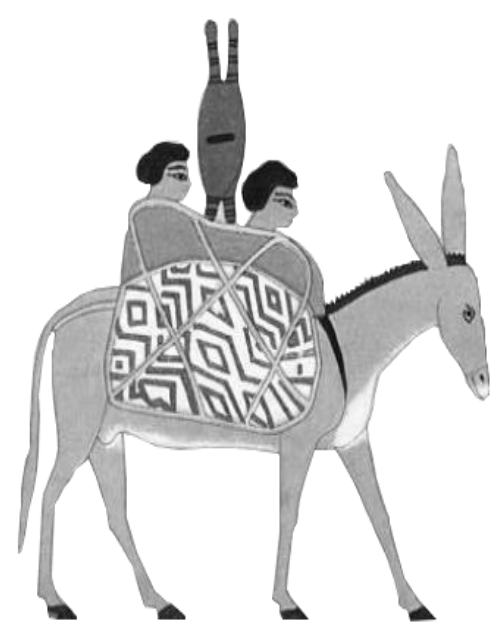

Fig. 7 Lepsius, 1913: pl. 133

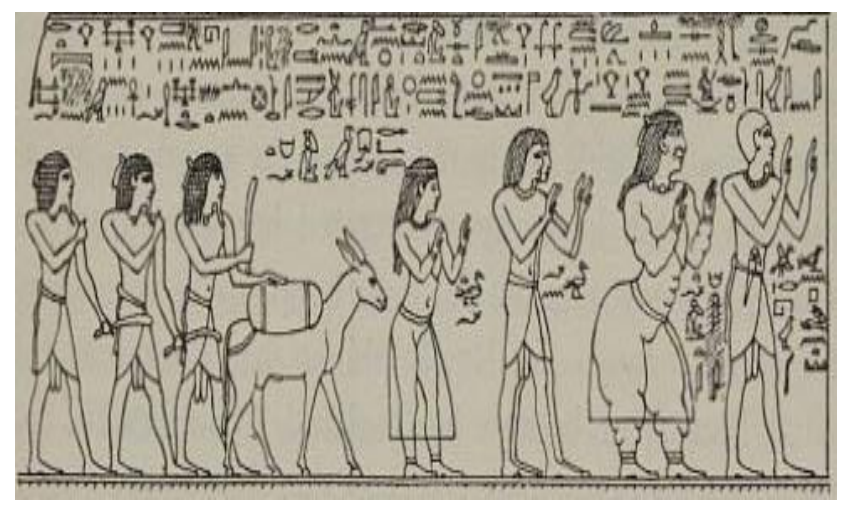

Fig.8 Mariette, 1877: pl.5 


\section{Loading Donkeys}

The typical scene shows men cutting barley, filling sacks, and loading donkeys, then driving donkeys and piling up sheaves beside the threshing floor (Smith: 1949: 188), as sums up by a line of inscription in front of the figure of PtahSekhem-Ankh (5 ${ }^{\text {th }}$ dynasty.) (Smith, 1960: 60; Smith (n. d): Fig. 31). The double panniers of the two bags loading also with other supplies and equipment (Lloyd, 2010: 384) Donkeys always represented with double panniers (Erman, 1894: 530), or two bags, one on each side (Donovan, and McCorquodale, 2000: 31, Fig. 4.17), but due to the Egyptian style of drawing the second back was hidden, the artist of the tomb of Iti ( $11^{\text {th }}$ dynasty.) for example, wanted to convey that the donkey was carrying two packs, rather than just one, and so the second basket was shown flipped upwards (Hagseth, 2005: 11, Fig. 1.1).

It is well known that the Egyptian artist arranged his scene from the vantage point of certain conceptual and aesthetic rather than visual criteria, this lead to some confusion to recent viewer (Nord, 2010: 33). To clear this confusion, two statuettes represented the panniers on the donkeys as it were in the real life; the wooden statuette from Assiyut dated to $12^{\text {th }}$ Dynasty in the Museum of Beaux Art, Lyon (Fig.9) (Hagseth, 2005: Fig. 1.1). The second is a clay statuette from Balat (Fig.10) (Boutantin, 1999: Fig.21, no. 71). These backs or loads over donkey's back were varied in its shape and size as seen in (table I), suitable for their limited capability, and easy to control.

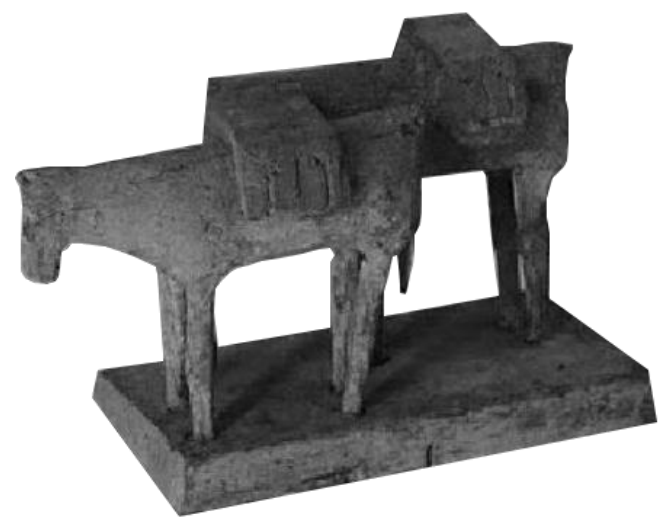

Fig .9 Hagseth, 2005: Fig. 1.1

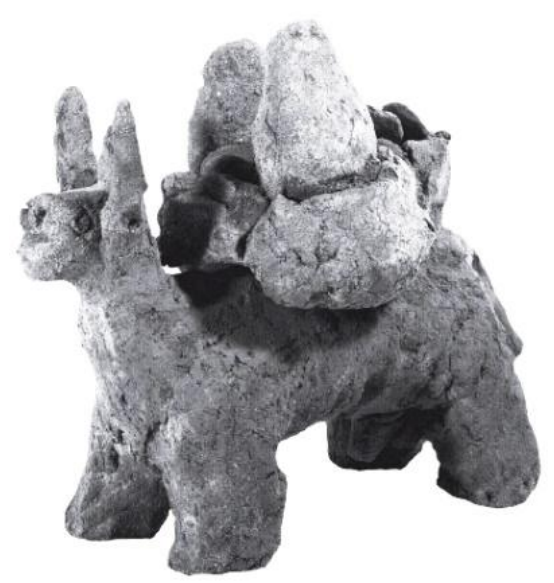

Fig.10 Boutantin, 1999: Fig. 21-no.71

In the tomb of Zau ( $5^{\text {th }}$ dynasty), the wheat harvest is seen carried off the field in rope nets on the back of donkeys and stacked in a pile ready for threshing (Fig.11) (Davies,1902:7, Fig. VI). Donkeys were not confined to load agriculture fields only, but unusual load was represented in the chapel of Niankhhknum and Khnumhotep ( $5^{\text {th }}$ dynasty.), where a group of baby Dorcas gazelles are being transported in a basket on the back of a donkey (Fig.12) (Harpur, and Scremin, 2010: Fig.263; Donovan, and McCorquodale, 2000; 85, Fig. 9.5). A relief from the tomb of Ukh-hotep $\left(12^{\text {th }}\right.$ dynasty) shows two men preparing and balancing the pannier over donkey's back (Fig. 13) (Blackman, 1915; PL. V). 


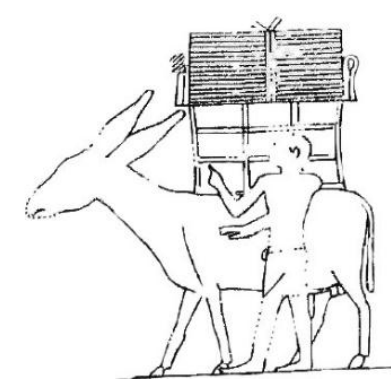

Fig.11 Davies, 1902: Fig. 6 Fig.12 Harpur\& Scremin, 2010:

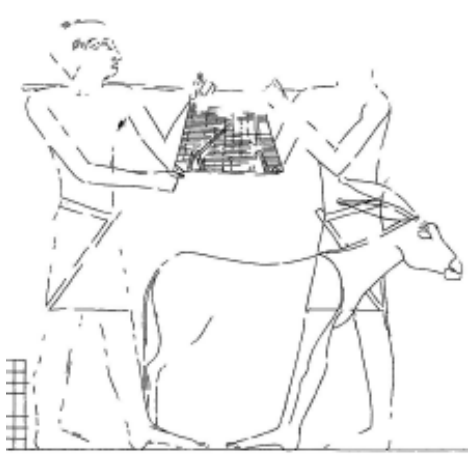

Fig.263 Fig. 13 Blackman, 1915: pl. V

\section{Controlling Donkey by stick}

Generally, most of the donkeys depicted in the tomb's wall were controlled by a driver holding a stick by his hand, to lead the stubborn animal.

A relief from the tomb of Neferbauptah at Giza ( $5^{\text {th }}$ dynasty), depicting the loaded donkeys bringing grain to Neferbauptah. A text above read: - $5 d t m$ sh $3 t$ "taking away with a herd of donkeys." The

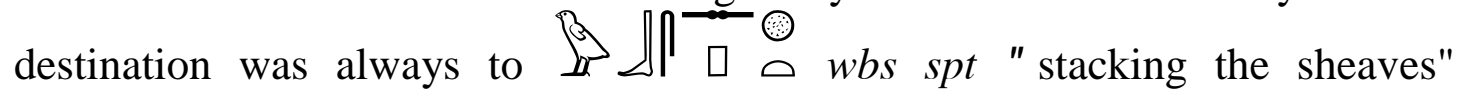
(Fig.14) (Weeks (I994: 22, Fig. 9; Junker, 1938; 42-43).

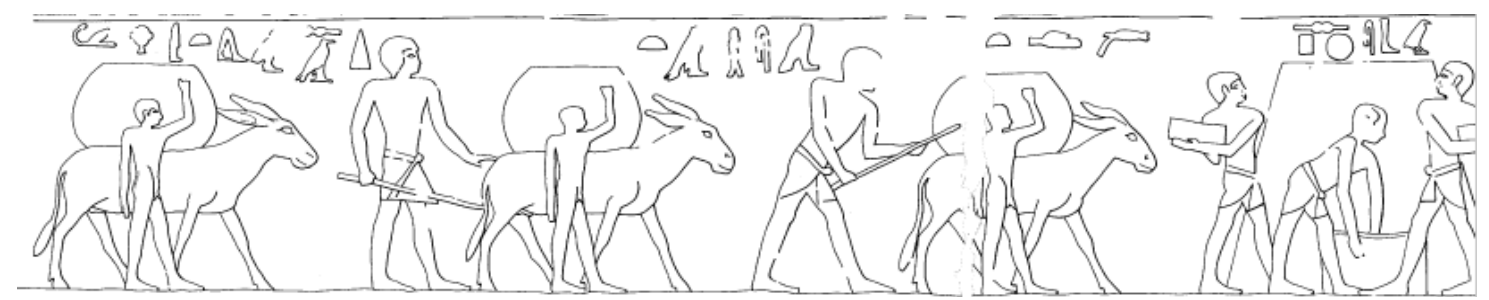

Fig.14 Weeks, I994: Fig. 9

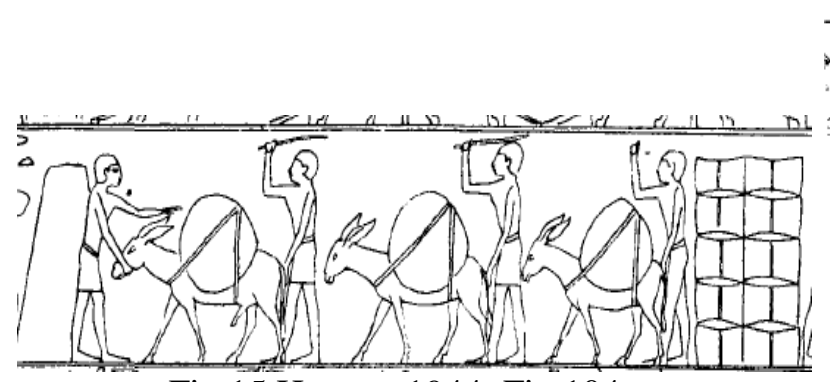

Fig.15 Hassan, 1944: Fig.104

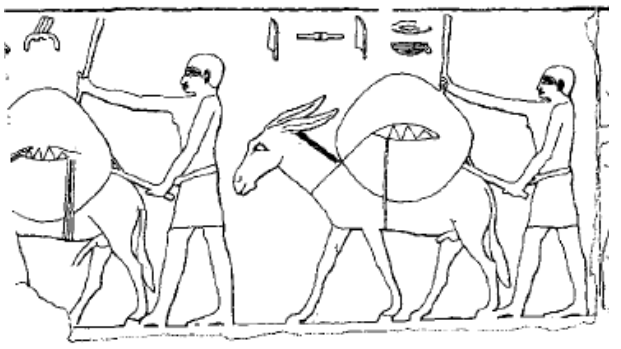

Fig.16 Hayes, (n. d): Fig. 57

A scene from the tomb of Iymery at Giza ( $5^{\text {th }}$ dynasty), represented four men drive two donkeys which are loaded with large sacks, behind each donkey walks a male figure in a short kilt holding a stick with both hands to urge the animal forward. A lade walks beside each donkey, who helps balance the donkeys' loads. The text above read; wbs spt "Stacking the sheaves" (Weeks, I994:48, Fig.39). Even more closely resembling such paintings as those from Gebelein in Turin Museum, and another model in Cairo showing two men driving donkeys loaded with heavy packs (Smith, 1949: 104, PL.60). 
A scene from the rock-cut-tomb of Werkhw ( $5^{\text {th }}$ dynasty), shows three donkeys laden with the sheaves, are driven off to the threshing-floor by three peasants waving sticks to fear him or strike his rump. A fourth man receives the donkeys and unloads them (Fig. 15) (Hassan, S (1944: PP.232, 244, 256, Fig.104; Lepsius, 1913: PL.43a).

A similar scene in the same tomb shows a drover behind a group of donkeys with a long stick up-raised saying: "Hey! I will whack you right on the rump." Other men then busily tie the sheaves in large panniers or sacks hung in pairs over the back of the donkeys (Hollihan 1996; 30, Fig.24, PL. XIII; Donovan, and McCorquodale, 2000: 89). In the tomb of Senedjemib ( $5^{\text {th }}$ dynasty) at Giza, a procession of laden donkeys with large sacks heading to the threshing floor. The convey controlling by sticks in the hands of the men and others balancing the loads (Brovarski, 2000: Fig.52b), this scene repeated in the tomb of Uhemka ( $5^{\text {th }}$ dyn.) (Kayser (1964: Fig. 17). While the tomb of Nefer $\left(5^{\text {th }}\right.$ dynasty) recorded a convoy of three donkeys were managed by two men three lads supporting the loads in their way to the threshing floor (Junker, 1943: Abb. $14,17)$, another loading scene in the mastabeh of Ra-em-kuy $\left(5^{\text {th }}\right.$ dyn.), King Isesy's eldest son every man holding a stick in each hand (Fig. 16) (Hayes, n. d: 101, Fig. 57). A typical agriculture relief where men driving loaded donkeys to the threshing floor was seen in the tomb of Ptah-Sehem-Ankh ( $5^{\text {th }}$ dynasty) (Smith, n. d: Fig. 31), Likewise in the tomb of Iasen (6 ${ }^{\text {th }}$ dynasty) a scene shows a lad balancing the load while a man behind waving by a stick to urge the donkey (Fig.17) (Simpson, 1980: Fig.30), and tomb of Seshemnefer at Giza ( $6^{\text {th }}$ dynasty), sharing the same scene (Kanawati, 2001: PL.40; Junker (1953: Abb. 74 a-b).

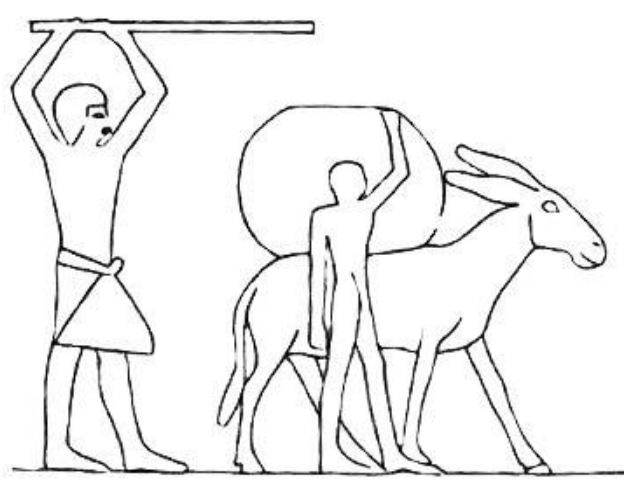

Fig.17 Simpson, 1980: Fig. 30

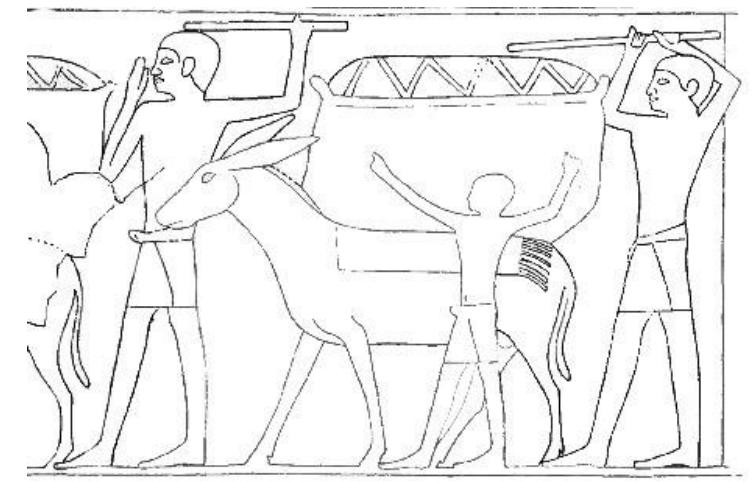

Fig.18 Junker, 1943: Abb. 45

A detailed scene from the tomb of Kahayef ( $6^{\text {th }}$ dynasty), shows the donkeys were escorted from the field in the company of several peasants, one man usually walking at the rear of each animal and waving a stick, the other walking at its side to support the load. The latter is often represented on a much smaller scale than his companion, and possibly a boy called into service to perform a task that required no skillful (Fig. 18) (Donovan and McCorquodale, 2000: 60, Fig. 7.13; Junker, 1943; 142, Abb. 45). This scene was repeated again, showing a donkey with saddle packs followed by a peasant in the tomb of Djar at Asasif (11 ${ }^{\text {th }}$ dynasty) (Wilkinson and Hill, 1983: Fig. 31,48; Smith, 
1981: 154, Fig. 147), In the tomb of Khety ( $11^{\text {th }}$ dynasty) a convoy of five donkeys small in size, saddled with panniers driven by two tall men each of them waving a stick by his hand to urge the animal (Newberry: 1893: 62, PL. XVII).

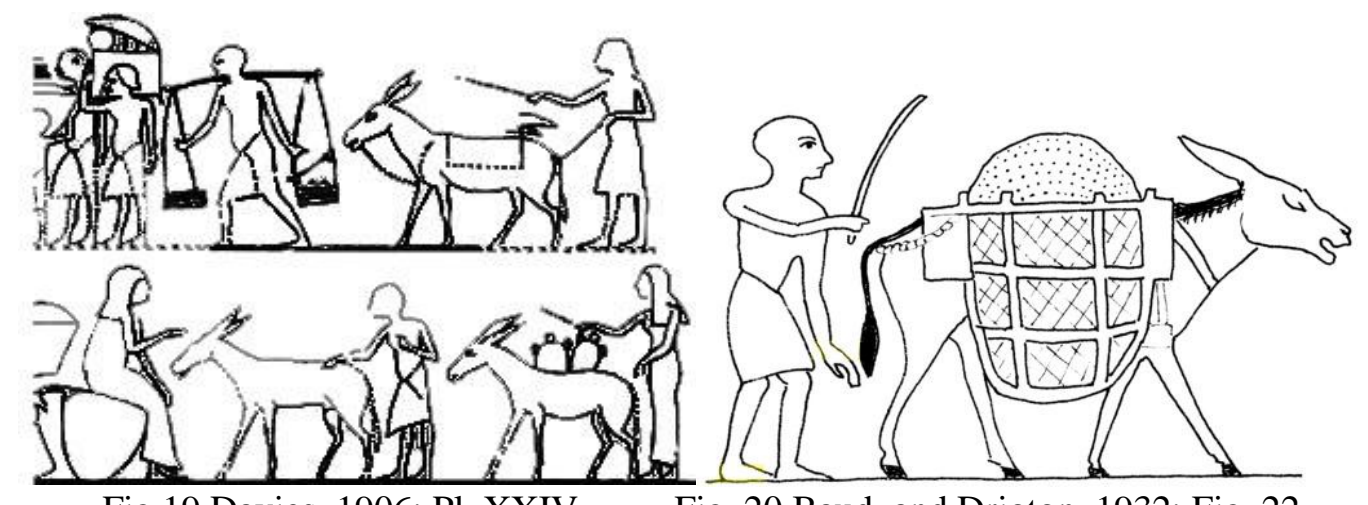

Fig.19 Davies, 1906: Pl. XXIV

Fig. 20 Baud, and Drioton, 1932: Fig. 22

A rare scene from the tomb of Mahu from El-Amarna $\left(18^{\text {th }}\right.$ dynasty), shows a women and a lad driving donkeys, loaded with fish, bread, water jars, and even flowers. Here this women used the stick also as a way to control the animal (Fig.19) (Davies, 1906: 17, PL. XXIV; Forster, 2007: 3, Fig. 32). In the tomb of Panehsy ( $18^{\text {th }}$ dynasty), two servants had managed the wheat and piled it in baskets, then loaded on donkeys. This operations not represented but we see a donkey walks away painfully with his load with the farmer behind strike his rump (Fig. 20) (Baud and Drioton, 1932: 42, Fig. 22; Peck, 2013: 77). A heavy loaded donkeys represented on a fragment in the Hildesheim, PelizaeusMuseum (Corpus, 1797: no 3191). Typically in the tomb of Ipuy at Deir elMedina (19 $9^{\text {th }}$ dyn.) (Wilkinson and Hill, 1983: Fig.48), and in the tomb of Apy, during the Ramesside period $19^{\text {th }}$ dynasty) (Davies, 1926: PL. XXXIX). (See table 2)

\section{Controlling donkey by Tugging tail, leg and headlock}

Although the ancient Egyptian peasants was not averse to using a rod on the backside of stubborn donkeys (Donovan, and McCorquodale 2000: 60-61; Hollihan (1996: 30, PL. XIII), where their legendary stubbornness was, of course, well-known in antiquity, and numerous vignettes capture farmers struggling with defiant beasts, as they attempt to get them to do some work (Collin, 2002: 106; Erman, 1894: 431). Peasants were represented in the reliefs and paintings controlling the animal by tugging on an ear or tail, lifting or pulling a leg, or even applying a headlock to the donkey.

Several scenes recorded this action like this scenes from the tomb of Urarna $\left(5^{\text {th }}\right.$ dynasty), representing two men and a lad controlling the animal. The man in the front head locked the donkey in one hand and supporting the load with his left hand (Fig.21) (Davies, 1901a: PL. XVI).

A heavy and difficult to control load in the tomb of Ti ( $5^{\text {th }}$ dynasty) has urged a group of peasants working together to manage a donkey's load which drifted during transportation. The four farmers strain to rebalance the load, bracing 
themselves against the donkey as well as the sack. One man head-lock the donkey while the man behind bulling his tail, the other two men involving to rebalance the shacking load (Fig. 22) (Donovan and McCorquodale, 2000: Fig. 7.14 Steindorf, 1913: tafet 124).
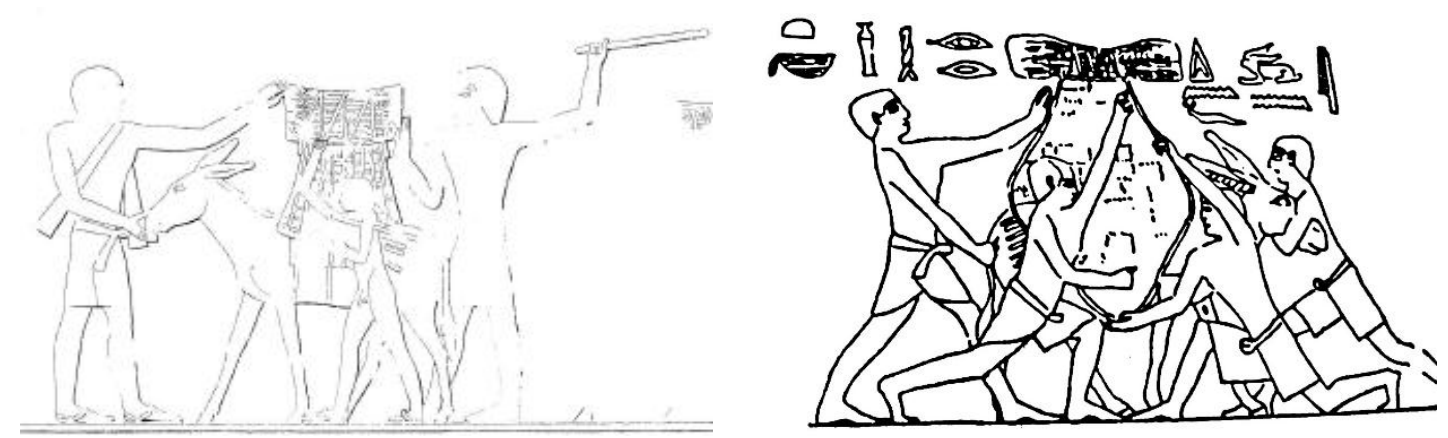

Fig.21 Davies, 1901: Pl. XVI

Fig.22 Donovan, and McCorquodale, 2000: Fig.7.14

The farmers in the tomb of Ptah Hotep ( $5^{\text {th }}$ dynasty) controlling the load on the backs of donkeys by head-locked the donkey (Fig.23) (Davies (1901: 13, PL. VII). The same tomb had a scene of a man holds a donkey by the ears and pulling the foreleg of the animal, with the intention either of making it standstill or of throwing it. (Fig.24) (Davies, 1901b: XI; Murray (1905: 15, PL. $\mathrm{XI}$ ). a similar scene in the tomb of Ptah hotep also, pulling the foreleg of the animal (Fig. 25) (Davies (1901b: PL.13, PL. VII). In the $5^{\text {th }}$ dynasty tombchapel of mastaba of Ti at Saqqara, a man holding the donkey by one foreleg and twisting an ear (Fig.26) (Steindorff, 1913: tafet 124; Donovan, and McCorquodale 2000: 60, Fig. 7.7). This scene was repeated typically in the tomb of Murruka but with two men, the one behind rested his right hand on donkey's back while his left hand tugged the tail of the donkey (Fig.27) (Junker, H., (1953; Abb. 75; Sakkarah Expedition, 1938: PL. 169-170). The representation of the donkey loaded with sheaves, panniers and other products repeated with similar attitudes in many tombs and becomes frequent during the $5^{\text {th }}$ Dynasty (Smith, 1949: PP. 172, 188), This act of controlling was seen also in the tomb of Merruka (6 ${ }^{\text {th }}$ dynasty) (Fig.28) (The Sakkarah Expedition, 1938: 196-170). A similar scene was also found in the tomb of Ahanekht (no. 5) at El-Bersheh (18 ${ }^{\text {th }}$ dynasty) (Griffith and Newberry, n. d: PL. XV), and in the tomb of Ti (Steindorff, 1913: tafet 122).

Fig.23

Fig. 24
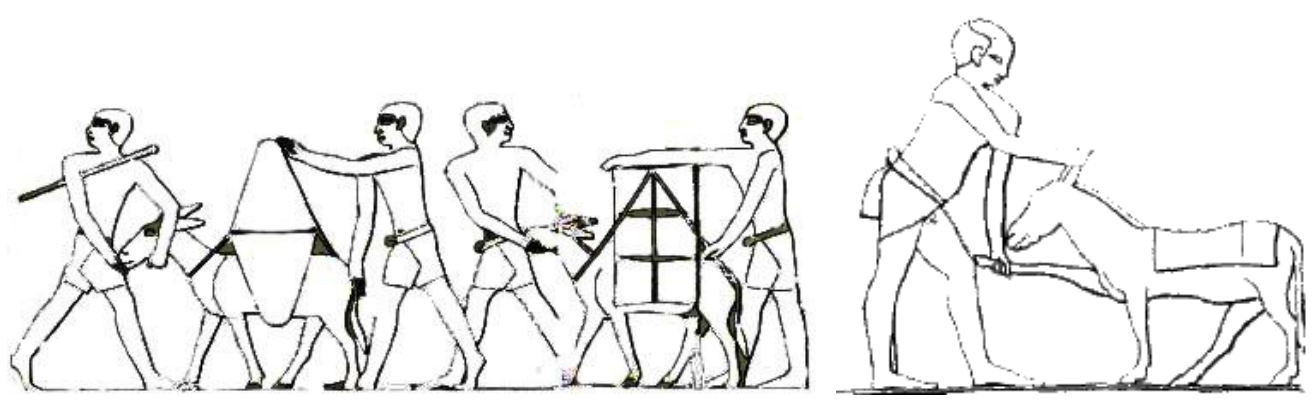

Fig.23 Davies, 1901: Pl. VII

Fig.24 Davies, 1901: Pl. XI 


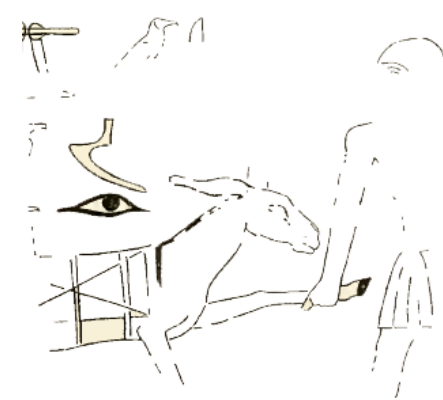

Fig.25 Davies, 1901: Pl. VII

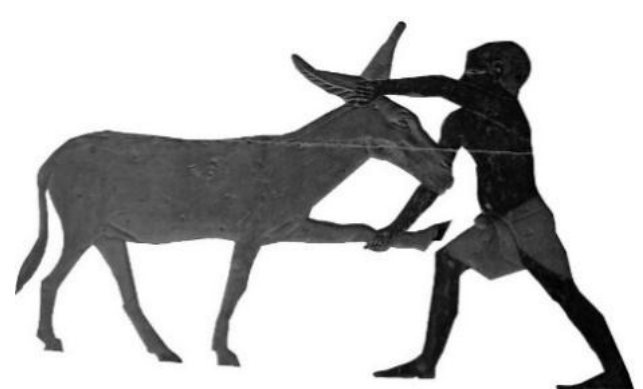

Fig.24 Donovan, and McCorquodale, 2000: pl. 7.7

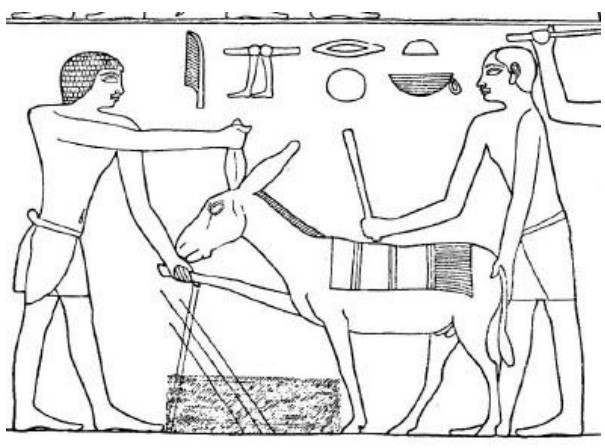

Fig.27 Junker, 1953: Abb.75

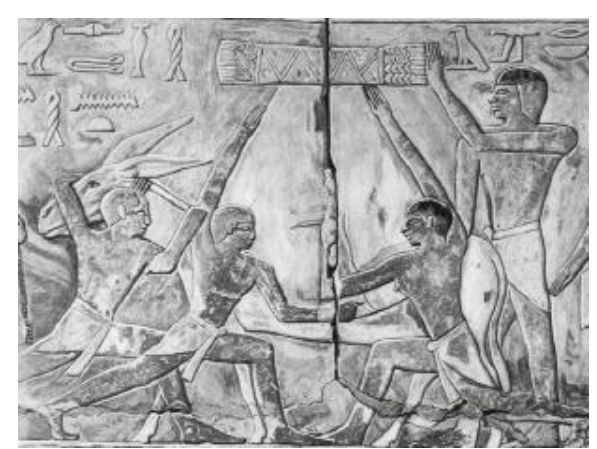

Fig.28 Sakkarah Expedition 1938: pl. 169-70

\section{Bad treatment}

The importance of donkeys in the daily lives of the Egyptians is highlighted by the fact that, at Deir el-Medina they were given names (Szpakowska, 2007: 20). Although there were cases of bad treatment as illustrated on a fragment of wall painting from the Frist Intermediate Period tomb of Ity at Gebelein $\left(11^{\text {th }}\right.$ dynasty), shows a donkey's rump bloodied that may have resulted from the blows delivered by the farmer's stick (Collins, 2002: 106; Hollihan, 1996: 30, PL. XIII; Donovan and McCorquodale, 2000: P.60; Baines and Malek, 2000: $82)$.

A letter from a man to his brother, reveals the cause of his ill donkey: "What does it mean that you tell me falsely things about the donkeys, (namely) that they are of no use to you? You said about the she-ass that she was ill from the (blow of the) stick..." (Janssen, 2005: 79). In Demotic magical papyri, there are words appearing as "a remedy for a donkey's not moving "(Ritner, 1993: 54). There were even disputing rates for donkeys that died before the contract period ended. (Cline, 2005: 136; Szpakowska, 2007: 20). Cases of abuse the animal were recorded such one case on Deir el-Medina which reveals a donkey eventually died after being beaten with a stick (Szpakowska, 2007: 20). The death of a donkey not only ascribed to bad treatment but also due to dehydration, where Quban stela stated that one expedition to gold mining at Wadi Allaqi lost half of their personnel and donkeys due to dehydration (Hebron, 2013: 44). Even after its death a donkey could still be useful where its skin was used for water. A limestone stela, badly damaged dates back to the $19^{\text {th }}$ or $20^{\text {th }}$ Dynasty, records the facts of using the skin of the donkeys for

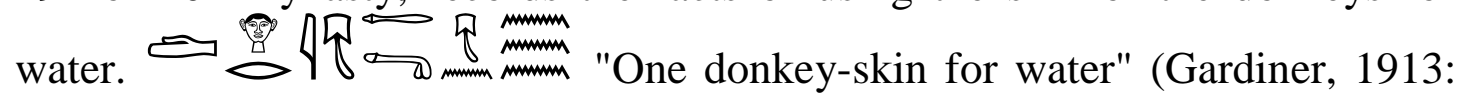
12). 


\section{Conclusion}

Most of the scene representing donkeys loading agriculture products, and all kinds of loads on donkey's back controlling by men holding a stick, even with those represented riding on donkey's back. Most of these illustrations dated back to the Old Kingdom, may be due to the abundance of agriculture scenes cover the wall of these tombs (table 1).

The easiest way of controlling the donkey, the ancient Egyptian assigned one or two men to do this task, by walking behind the donkey using a stick. This way is still using today. Women also sharing men this task (table 2). The ancient Egyptian accustomed to use several ways of treatment. Controlling the animal takes several shapes by stick, dragging the foreleg, bulling the ear, tugging tail, and head-lock. All of these ways representing as a hard act suitable in ancient Egyptian view to this stubborn and deviated animal. Sometimes they strike the donkey's rump or waving by a stick to fear him or urge him to hurry. Using a stick was also recorded by men from Asiatic origins.

Donkeys were used to load several kinds of products from agriculture to everyday products and even bearing water. These loads were varied in its shape and size from small to large (table 3). The ancient Egyptian never intended to abuse donkeys in order to control them, but due to the stubborn and defiant nature of the donkey, the Egyptian have to hold a stick to urge the animal to hurry or sometimes beat him when he feels the donkey deviate from the right bath, although, some cases recorded the use of violence which led sometimes to the death of the donkey. Although rare scenes highlighted the pain and wounds over the donkey's body. Some cases of the death resulted from abusing or the dehydration in the remote deserted working area. Even after his death, they using his skin for water.

Table 1: A list of tombs mentioned in the paper

\begin{tabular}{|l|l|l|l|}
\hline No. & \multicolumn{1}{|c|}{ tomb } & \multicolumn{1}{c|}{ period } & \multicolumn{1}{c|}{ location } \\
\hline 1 & Khuwiwer & $5^{\text {th }}$ dynasty & Giza \\
\hline 2 & $\begin{array}{l}\text { Niankhkhnum } \\
\text { \&khnumhotep }\end{array}$ & $5^{\text {th }}$ dynasty & Saqqara \\
\hline 3 & Zau & $5^{\text {th }}$ dynasty & Deir el-Gebrawi \\
\hline 4 & Neferbauptah & $5^{\text {th }}$ dynasty & Giza \\
\hline 5 & Iymery & $5^{\text {th }}$ dynasty & Giza \\
\hline 6 & Werkhw & $5^{\text {th }}$ dynasty & Giza \\
\hline 7 & Seneedjemib & End of $5^{\text {th }}$ dynasty & Giza \\
\hline 8 & Uhemka & Beginning of $5^{\text {th }}$ dynasty & Giza \\
\hline 9 & Nefer $(G 2110)$ & Late $5^{\text {th }}$ dynasty & Giza \\
\hline 10 & Ra-em-kuy & $5^{\text {th }}$ dynasty & Saqara \\
\hline 11 & Ptah-Sehem-Ankh & $5^{\text {th }}$ dynasty & Saqara \\
\hline 12 & Urarna & $5^{\text {th }}$ dynasty & Sheikh Said \\
\hline 13 & Ti & $5^{\text {th }}$ dynasty & Saqara \\
\hline 14 & Ptah Hotep & $5^{\text {th }}$ dynasty & Saqqara \\
\hline
\end{tabular}




\begin{tabular}{|l|l|l|l|}
\hline 15 & Ahanekht (No. 5) & Early M.K & El-Bersheh \\
\hline 16 & Ity & $11^{\text {th }}$ dynasty & Gebelein \\
\hline 17 & Iasen & ${\text { From } 4^{\text {th }} \text { to } 6^{\text {th }} \text { dynasties }}^{\text { }}$ & Giza \\
\hline 18 & Seshemnefer & Early $^{\text {th }}$ dynasty & Giza \\
\hline 19 & Kahayef & $6^{\text {th }}$ dynasty & Giza \\
\hline 20 & Merruka & $6^{\text {th }}$ dynasty & Saqara \\
\hline 21 & Khety & $11^{\text {th }}$ dynasty & Beni Hasan \\
\hline 22 & Djar & $11^{\text {th }}$ dynasty & Asasif \\
\hline 23 & Khnumhotep III & $12^{\text {th }}$ dynasty & Beni Hassan \\
\hline 24 & Ukh-hotep ( no.2) & $12^{\text {th }}$ dynasty & Meir \\
\hline 25 & Panehsy & $18^{\text {th }}$ dynasty & Dira Abu'n-Naga \\
\hline 26 & Mahu & $18^{\text {th }}$ dynasty & El-Amarna \\
\hline 27 & Apy & $19^{\text {th }}$ dynasty & Deir el-Medina \\
\hline 28 & Ipuy & $19^{\text {th }}$ dynasty & Deir el-Medina \\
\hline
\end{tabular}

Table 2: Different kinds of Loads over donkeys

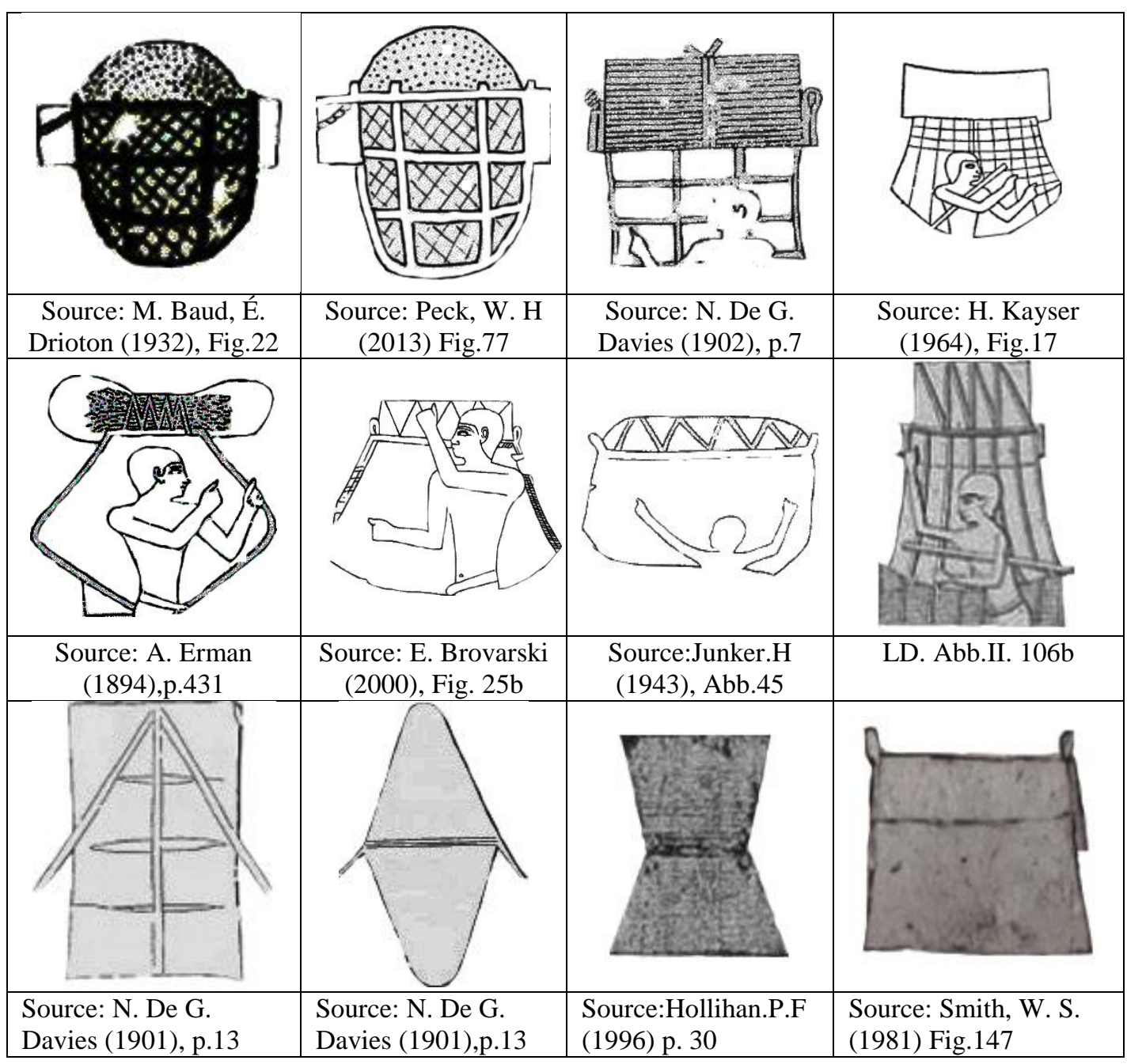




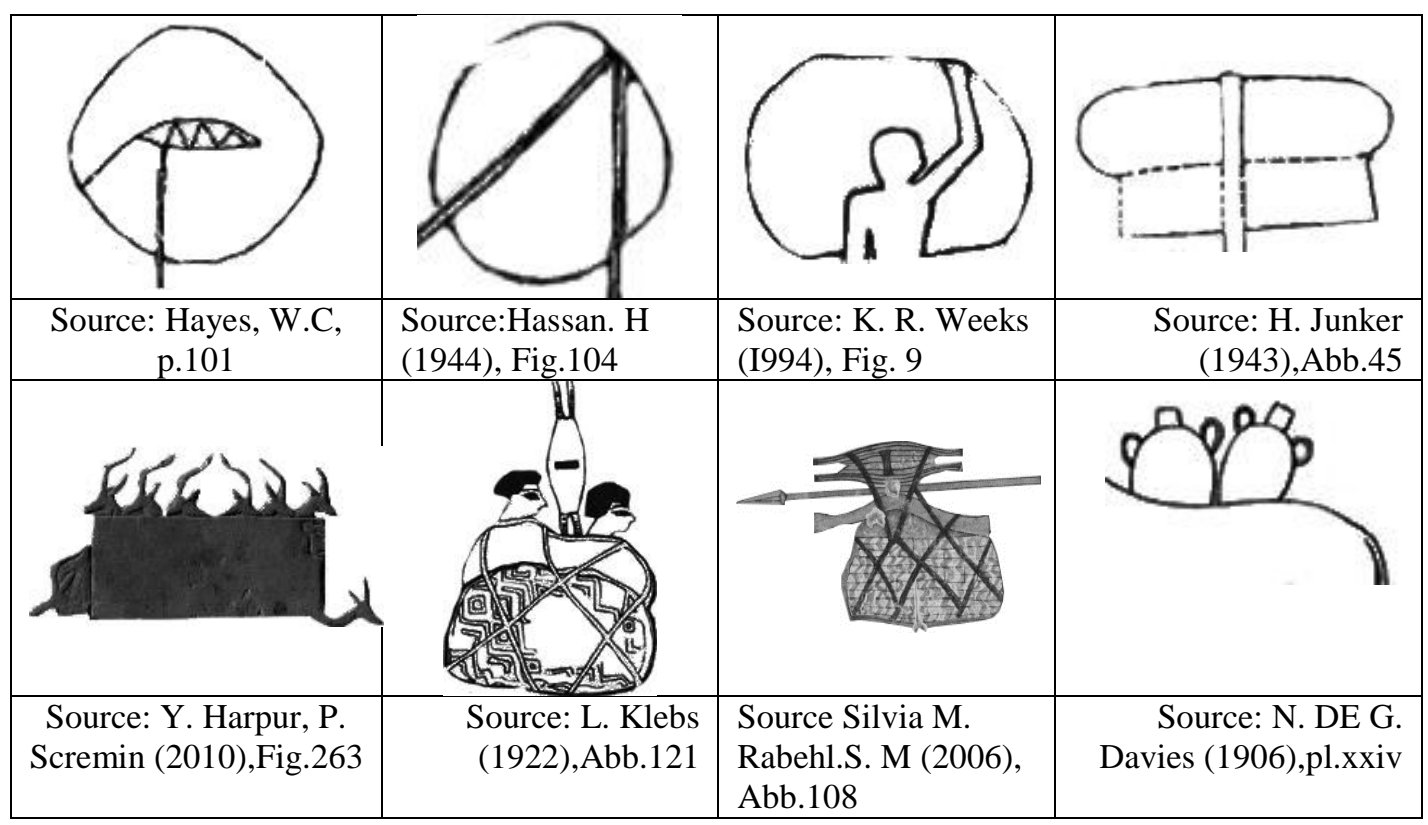

Table 3: Different positions of sticks in the hands of farmers

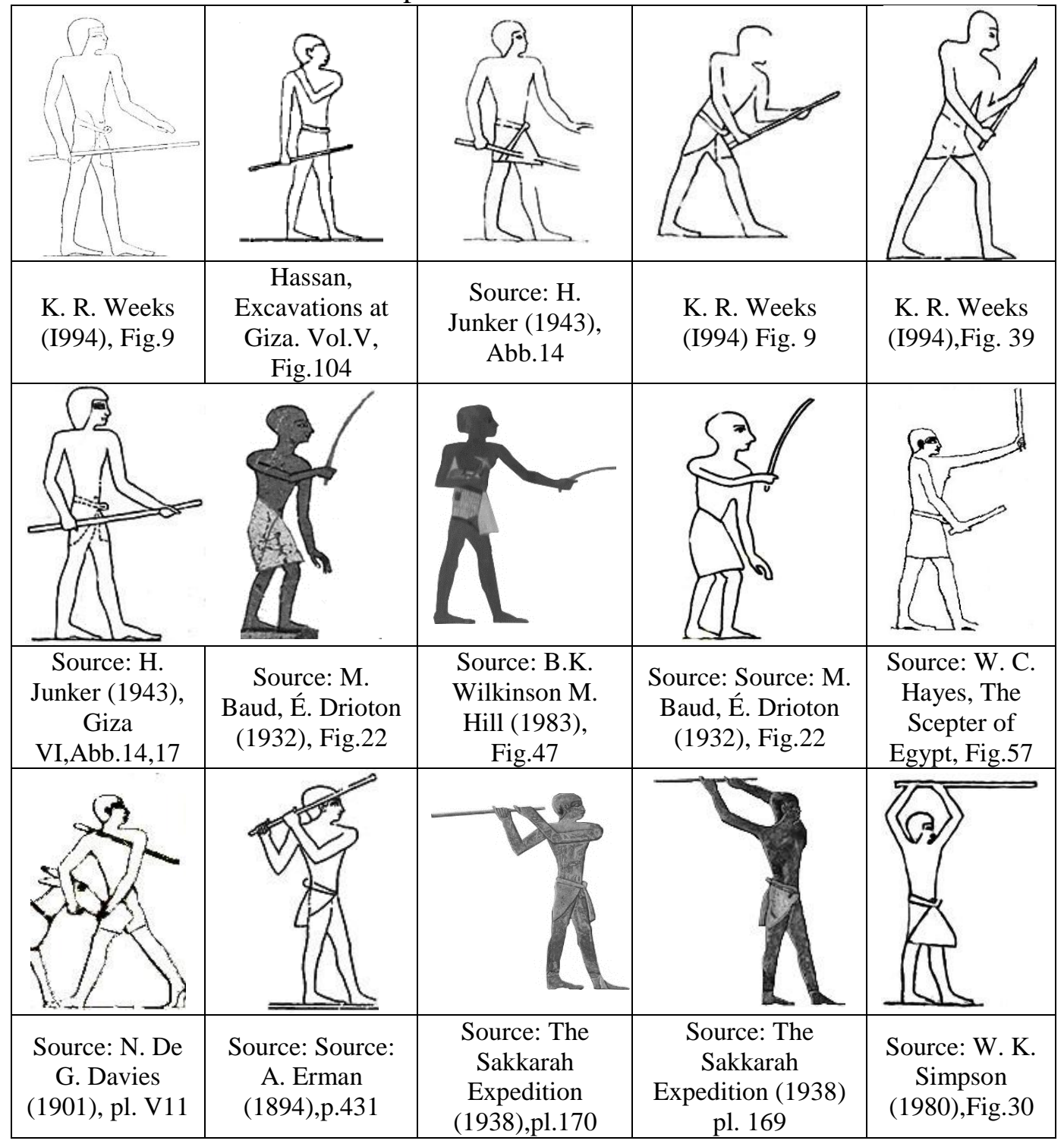




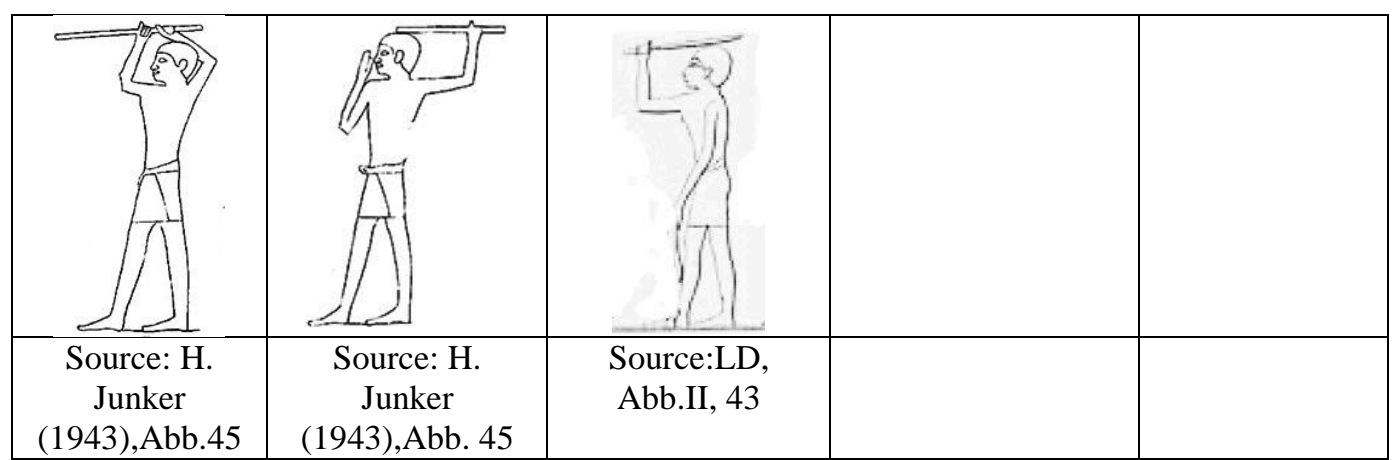

\section{Bibliography}

Altenmüller, A. M., and Moussa, H. (1977) Das Grab Des Nianchchnum und Chnumhotep: German Institute of Archaeology, Cairo.

Bárta, M. (2011) Journy to the West, Charles University in Prague, Faculty of Arts, Prague.

Boutantin, C, (1999) Le Figurines en terre crue de la nécropole de Balat, BIFAO 99, Institut français d'archéologie Orientale - Le Caire Blackman, A. M (1915). The Rock Tombs of Meir II, London Brovarski, E (2000). The Senedjemib Complex I, Museum of Fine Arts, Boston.

Baud, M. and Drioton, É, (1932). Nécropole de Dira Abu'n-Naga, Le Tombeau de Panehsy (MIFAO) 57/2, Imprimerie de L'institut Français d'Archéologie Orientale, Le Caire.

Baines, J. Malek, (2000) Cultural Atlas of Ancient Egypt, Checkmark Books, New York.

Bard, K. A and Shubert, S. B (2005). Encyclopedia of the Archaeology of Ancient Egypt, Routledge, London and New York.

Bunson, M. R, (2002). Encyclopedia of Ancient Egypt, Facts On File, New York.

Bard, K. A and Shubert, S. B (1999), Encyclopedia of the Archaeology of Ancient Egypt. Routledge, London \& New York.

Capart (1905), Primitive Art in Egypt, London.

Cline E.H., and Rubalcaba, J, (2005). The Ancient Egyptian World, Oxford University Press, New York.

Collins, B. J, (2002). A history of the Animal world in the Ancient Near East, Brill, Netherlands

Country Life in Ancient Egypt, Museum of Fine Arts, Boston, USA Corpus Antiquitatum Aegyptiacarum 7 (1979), Pelizaeus-Museum, Hildesheim, Germany, 3191

Cline E.H. Rubalcaba, J, (2005). The Ancient Egyptian World, Oxford University Press, New York.

David, R, (2003), Handbook to life in Ancient Egypt, New York. Donovan, L and McCorquodale, K, (ed.) (2000) Egyptian Art, Foreign Cultural information Department. Cairo.

Davies, N. De G., (1927). Two Ramessside Tombs at Thebes, New York. (1906). The Rock Tombs of El Amarna, part IV, London. . (1902). The Rock Tomb of Deir el Gebrawi II, London 
(1901a). The Rock Tombs of Sheikh Said, London. (1901b). The Mastaba of Ptahhetep and Akhethetep at

Saqqareh II, London.

Erman, A, (1894). Life in Ancient Egypt, London \& New York.

Forster, F, (2007). With donkeys, Jars and water bags into Libyan Desert; The

Abu Ballas Trail in the Late Old Kingdom/first Intermediate

Period, BMSAES 7, London.

Gardiner, A. H. (1913) Theban Ostraca, part I, Oxford University Press, Oxford.

Gadiner, A. H and Peet, T.E, (1955). The Inscriptions of Sinai I-II, Oxford University press, London.

Griffith, F.L. and Newberry, P.E (n. d), El Bersheh II, London.

Hawass, Z, (2010). Inside the Egyptian Museum, AUC press, Cairo.

Holihan, P. H, (1995). The Animal World of the Pharaohs, AUC Press, Cairo.

Hassan, S (1944) Excavations at Giza. Vol. V, Cairo.

Hagseth, M. C (2005). Nilotic Livestock Transport in Ancient Egypt.

(Unpublished Master Degree), Texas A\&M University, Megan

Christine Hagseth, Texas

Nord, D, (2010). Under the Chair: A problem in Egyptian Perspective, in

Supplément aux Annalles du Service des Antiquités de L'Égypte,

Chair No. 39/II, Le Caire.

Harpur, Y and Scremin, P, (2010). The Chapel of Niankhhknum \&

Khnumhotep, Oxford.

Hayes, W. C, (n. d).The Scepter of Egypt I, Plantin press, New York.

Hassan, S, (1944). Excavations at Giza. Vol. V, Government Press, Cairo.

Hebron, C. S, (2013) Aspects of Health, Injury and Disease among the Nonelite

Workforce of Dynastic Egypt (PhD), Institute Of Archaeology

University College London. Published by ProQuest LLC

Janssen, J, (2005). Donkeys at Deir el-Medina, the Netherlands Institute for the Near East, Leiden.

Junker, H, (1938). Giza. Vol. III, Grabungen auf dem Friendhof des Alten

Reiches, Leipzig.

. (1943), Giza VI, Grabungen auf dem Friendhof des Alten Reiches,

Leipzig.

(1953), Giza XI, Grabungen auf dem Friendhof des Alten Reiches,

Leipzig.

Kopp-junk, H, (2013) The Chariot as a Mode of Locomotion in civil contexts" in Chasing Chariots: Proceedings of the Frist International Chariot

Conference, Sidestone Press, Leiden.

Kayser, H, (1964). Die Mastaba des Uhemka, Hannover.

Kanawati, N (2001), Tombs at Giza I, the Australian Centre for Egyptology,

England.

Klebs, L (1922), Die Reliefs und Malereien des Mitteren Reiches, Heidelberg.

LIoyd, A. B (2010). A Companion to Ancient Egypt, Vol. I, Blackwell

Publishing Ltd, Oxford. 
Lsko, L. H,(1994). Pharaoh's Workers: The Villagers of Deir El Medina, Cornell

University Press.

Littauer, M. A \& Crouwel, J. H (1979) Wheeled Vehicles and Ridden Animals in the Ancient near East, Leiden/ Kŏln, E.J. Brill.

Lepsius, R, (1913) Denkmäler des Alten Reiches. II, J. C. Hinrichs's

Buchhandlung, Leipzig.

Muhs, B, (2016). The Ancient Egyptian Economy, Cambridge University Press. Mariette, A, (1877), Deir el Bahari, Le Caire \& Paris.

Monderson, F (2007), Hatshepsut's temple at Deir el Bahari, Authorhouse, Indiana

Murray, M. A, (1905), Saqqara Mastabas I, Bernard Quaritch, London.

Malek, J, (1986). In the Shadow of the Pyramids, AUC press, Cairo.

McCorquodale, K, (2000) Characteristics and Style of Egyptian Art from the Old Kingdom to the Middle Kingdom, in Egyptian Art, Foreign cultural information department, Cairo.

Nicholson, P.T \& Shaw, I, (2000) Ancient Egyptian Materials and Technology, Cambridge University Press, Cambridge.

Newberry, P.E, (1893) Beni Hasan I, Kegan Paul, Trench, Trübner \& Co., Ltd. London.

(1893), Beni Hasan II, Kegan Paul, Trench, Trübner \& Co., Ltd. London.

Naville, E, (1898) Temple of Deir el Bahari III, Egypt Exploration Fund, London.

Peck, W.H, (2013). The Material World of Ancient Egypt, Cambridge University

Press, Cambridge.

Partridge, R. B, (1996), Transport in Ancient Egypt, Rubicon, London.

Redford, S, (2001). The Oxford Encyclopedia of Ancient Egypt, Vol. I, Oxford.

Ritner. R. K, (1993).The Mechanics of Ancient Egyptian Magical Practice. The Oriental Institute of the University of Chicago, Chicago.

Redford, S, (2001) The Oxford Encyclopedia of Ancient Egypt, Vol. I, Oxford. Cultural information Dept. Cairo.

Simpson, W. K, (2003) Literature of Ancient Egypt, 3rd ed., Yale University, London.

Smith, W. S, (1981) the Art and Architecture of Ancient Egypt, New York (1960), Ancient Egypt, Museum of Fine Arts, Boston. (1949). A History of Egyptian Sculpture and Painting in the Old Kingdom, 2nd ed., Museum of Fine Arts, Boston.

Boston.
Scanlan, B, (2000), Animals: The Hunted and the Domesticated, in Egyptian (n. d) Country life in Ancient Egypt, Museum of Fine Arts, Art, Foreign Cultural information department. Cairo.

Sethe, K (1914) Urkunden Der 18. Dynastie VI, 1, Leipzig 
Simpson, W. K, (1980). Mastabas of the Western Cemetery, Museum of Fine Arts, Boston.

Steindorf, G, (1913) Das Grab Des Ti, Leipzig.

The Sakkarah Expedition (1938). The Mastaba of Mereruka II, the University of Chicago press, Chicago- Illinois.

Szpakowska, K, (2007), Daily Life in Ancient Egypt, Blackwell Publishing, London-New York.

Wilkison, T. A. H, (1999). Early Dynastic Egypt, Routledge Press, London Wilkinson, T, (2007). The Egyptian World, Routledge Press, New York.

Woldering, I, (1962). The Art of Egypt, Greystone Press, New York.

Weeks, K. R, (I994), Cemetery G 6000, Museum of Fine Arts, Boston. Arts, Boston

Wilkinson, C. K, and Hill, M, (1983), Egyptian Paintings, The metropolitan Museum of Art, New York.

\section{صور لامتطاء وتحميل ومعاملة الحمار كحيوان حمل في مصر القديمة}

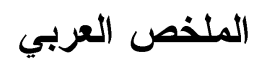

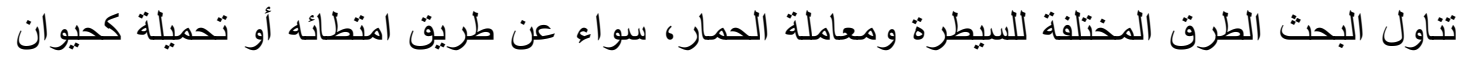

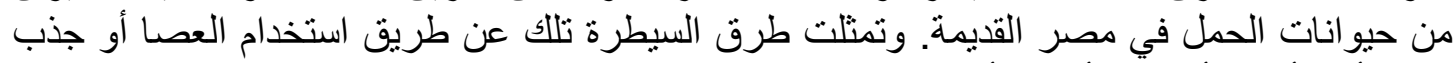

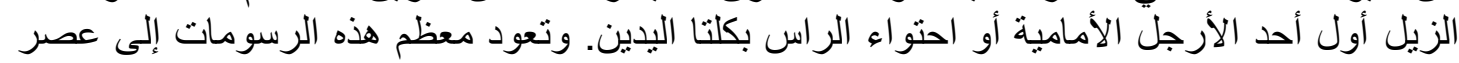

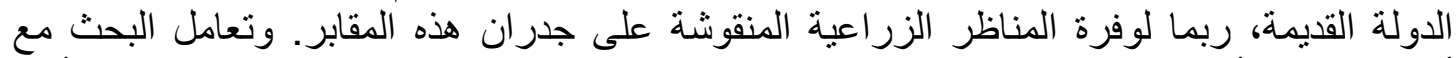

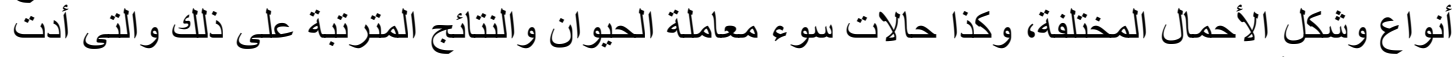
في بعض الأحيان إلى موته.

الكلمات الالةة: حمار، تحميل، عصا، سبطرة، معاملة، احتو اء، سلة. 